\title{
Pencegahan Terjadinya Bahaya dan Adverse Event Oleh Pasien dan
}

\author{
Keluarga \\ Adisty Olyvia Hutagalung \\ Adistyhutagalung@gmail.com
}

\section{Latar Belakang}

Menurut Vincent (2008), keselamatan pasien didefinisikan sebagai penghindaran, pencegahan dan perbaikan dari hasil tindakan yang buruk atau injuri yang berasal dari proses perawatan kesehatan.

Keselamatan Pasien (Patient Safety) merupakan sesuatu yang jauh lebih penting dari pada sekedar efisiensi pelayanan. Perilaku perawat dengan kemampuan perawat sangat berperan penting dalam pelaksanaan keselamatan pasien. Perilaku yang tidak aman, lupa, kurangnya perhatian/motivasi, kecerobohan, tidak teliti dan kemampuan yang tidak memperdulikan dan menjaga keselamatan pasien berisiko untuk terjadinya kesalahan dan akan mengakibatkan cedera pada pasien, berupa Near Miss (Kejadian Nyaris Cedera/KNC) atau Adverse Event (Kejadian Tidak Diharapkan/KTD) selanjutnya pengurangan kesalahan dapat dicapai dengan memodifikasi perilaku.

Mengingat masalah keselamatan pasien merupakan masalah yang perlu ditangani segera di fasilitas pelayanan kesehatan di Indonesia maka diperlukan standar keselamatan pasien fasilitas pelayanan kesehatan yang merupakan acuan bagi fasilitas pelayanan kesehatan di Indonesia untuk melaksanakan kegiatannya.

Salah satu standarnya adalah fasilitas pelayanan kesehatan harus mendidik pasien dan keluarganya tentang kewajiban dan tanggung jawab pasien dalam asuhan pasien. Kriterianya adalah keselamatan dalam pemberian pelayanan dapat ditingkatkan dengan keterlibatan pasien yang merupakan partner dalam proses pelayanan. Karena itu, di fasilitas pelayanan kesehatan harus ada sistem dan mekanisme mendidik pasien dan keluarganya tentang kewajiban dan tanggung jawab pasien dalam asuhan pasien.

Keluarga sebagai lingkungan terdekat pasien merupakan sumber pengetahuan dan persepsi individu terhadap kesehatan. Partisipasi keluarga dan agama menjadi kunci pengelolaan kualitas hidup pada pasien. Oleh karena itu diperlukan pengelolaan masalah kesehatan yang tidak hanya terfokus pada pasien, tetapi juga pada keluarga. Pendekatan kepada 
keluarga dapat dilakukan untuk mengupayakan kesehatan individu, keluarga, dan masyarakat yang lebih baik. Pelayanan berorientasi keluarga dapat memetakan kebutuhan keluarga dan melihat kondisi keluarga dari perspektif pasien sehingga tercapai penyamaan persepsi antara pasien, keluarga, dan tenaga kesehatan.

Oleh karena itu, dilakukan penelitian yang bertujuan untuk menganalisa peran pasien dan keluarga dalam mencegah terjadinya bahaya dan adverse event (kejadian tidak diharapkan).

\section{Metode}

Metode yang digunakan adalah literature review. Kajian literature meninjau literatur ilmiah tentang sebuah topik dan secara kritis menganalisis, mengevaluasi, dan menyintesis temuan penelitian, teori, dan praktik. Pencarian artikel penelitian menggunakan jurnal, tesis, skripsi, disertasi, artikel dan lainnya dengan menggunakan kata kunci yaitu pencegahan bahaya, pencegahan KTD, peran pasien dan keluarga, adverse event, K3. Kriteria inklusi yaitu artikel full text yang berbahasa Inggris atau berbahasa Indonesia dipublikasikan dengan tahun paling lama 2012. Jumlah keseluruhan artikel yang didapatkan dilakukan penyaringan sesuai dengan kriteria inklusi sehingga hasil akhir ditemukan 10 artikel yang di review.

\section{Hasil}

Dalam JKEP (2020) Pendekatan pendidikan kesehatan lebih tepat dibandingkan dengan pendekatan koersi untuk melakukan pembinaan dan peningkatan perilaku kesehatan masyarakat, karena melalui pendidikan akan terjadi penambahan pengetahuan. Sehingga apabila keluarga mendapatkan informasi tentang cara pencegahan risiko jatuh, maka keluarga dapat berfikir dan dan dapat menerapkannya pada anggota keluarganya sesuai dengan pengetahuan yang diterimanya.

Dalam NurseLine Journal (2018) Pada saat dilakukan wawancara dengan keluarga pasien data bahwa keluarga pasien menganggap jatuh merupakan hal yang wajar bila terjadi pada anak dan tidak diperlukan pencegahan khusus. Saat dilakukan observasi pada perawat yang memberikan edukasi pencegahan jatuh, didapatkan data keluarga pasien tidak menaikkan pengaman tempat tidur karena anak ditunggu oleh kedua orang tua dan tidak dipasang gelang kuning pada 1 orang pasien karena lupa. Dari data tersebut dapat diambil kesimpulan bahwa perawat telah melaksanakan pengkajian risiko jatuh dengan baik tetapi pelaksanaan pencegahan jatuh belum optimal dan berisiko terhadap kejadian pasien jatuh. Hal ini dapat 
dipengaruhi oleh berbagai faktor. Kemungkinan penyebabnya yaitu faktor perawat yang belum patuh pada standar prosedur operasional atau faktor keluarga pasien yang tidak berperan aktif dalam pencegahan jatuh.

Dalam Skripsi (2017) Keluarga adalah supporting system yang sangat penting dalam proses penyembuhan pasien. Secara konsep, kondisi sehat biasanya pasien membutuhkan pemenuhan kebutuhan akan psikososial yang merupakan fungsi internal keluarga. Kondisi sakit pasien lebih membutuhkan rasa aman dan nyaman ketika keluarga berada didekat pasien. Kondisi fisik keluarga pasien yang tidak stabil, juga membuat mereka rentan terhadap resiko gangguan psikologis seperti stress, kecemasan, gangguan mental hingga depresi.

Dalam Jurnal Ners Indonesia (2019) Hasil penelitian sejalan dengan teori yang dikemukakan oleh Dion dan Betan, (2013), yang mengatakan bahwa salah satu penatalaksanaan pada pasien risiko perilaku kekerasan adalah terapi keluarga seperti kunjungan keluarga. dimana kunjungan keluarga ini akan membangun rasa saling menyayangi, saling asuh, menerima anggota keluarga, mendukung antar anggota keluarga, memberi perhatian satu sama lain memberi cinta kasih dan memberi kehangatan.

\section{Pembahasan}

Dalam masyarakat umum masih ada suatu keluarga yang terdiri dari bapak/ibu, anak yang sudah menikah dan memiliki beberapa cucu. (Hartomo:1999). Hubungan tersebut berjalan baik dan harmonis karena adanya penurunan nilai - nilai budaya, aturan agama yang mengharuskan setiap anggota keluarga saling mengasihi dan ikut merasakan penderitaan anggota dalam keluarga tersebut apalagi orang tua yang sudah melahirkan dan membesarkan hingga mereka dewasa.

Dengan bantuan perhatian perhatian dan bimbingan kedua orang tuanya, pasien merasa damai serta dapat melakukan aktifitas sederhana. Seorang ayah/ibu masing - masing memiliki peran yang sama dalam membesarkan dan membimbing anak - anaknya. Seorang ayah dianggap sebagai kepala keluarga yang diharapkan mempunyai sifat kepemimpinan. Seorang pemimpin harus dapat memberikan teladan yang baik, memberikan semangat untuk berkembangnya kreatif anak. Seorang ibu berperan sebagai proses terjadinya sosialisasi awal bagi kehidupan seorang anak. Sehingga jika sianak mengalami persoalan dia akan kembali kepada ibu / bapaknya untuk memberikan perlindungan. 
Hasil penelitian juga mengungkapkan peran ibu sangat menentukan karena secara psikologi hubungan ibu dengan anak tidak dapat dipisahkan walau sianak sudah bekerja dan mandiri. Hubungan tersebut tidak akan terputus apalagi jika sianak dalam keadaan sakit yang kondisinya berbeda dari penyakit masyarakat kebanyakan.

Hasil survey didapatkan pasien mengatakan bahwa keluarga sangat berperan dalam membantu, selain itu peran petugas kesehatan sangat penting dalam memberikan pengetahuan dan penyuluhan.

Dukungan keluarga ialah sikap, tindakan dan penerimaan keluarga terhadap penderita yang sakit. Anggota keluarga memandang bahwa orang yang bersifat mendukung selalu siap memberikan pertolongan dan bantuan yang diperlukan. Pasien yang mendapat dukungan keluarga merasa aman, nyaman, perasaan dihargai, diperhatikan dan dicintai sehingga dapat mengurangi atau menghilangkan kecemasan (Harnilawati, 2013).

Menurut teori Supartini (2011) mengatakan bahwa dukungan keluarga dapat mempengaruhi tingkat kecemasan seseorang. Hal ini disebabkan karena keadaan seseorang, emosional individu yang tidak terkontrol sering berkaitan dengan perasaan yang tak pasti dan tidak berdaya. Keadaan emosi ini tidak memiliki subyek yang spesifik, kondisi ini dialami secara subyektif yang hanya dirasakan individu tersebut dan dikomunikasikan dalam hubungan interpersonal akan menimbulkan efek kecemasan pada dirinya.

Menurut asumsi peneliti, dukungan yang baik dari keluarga akan mempengaruhi tingkat kecemasan responden sehingga dapat memberikan sikap yang positif. Dukungan keluarga mempunyai pengaruh yang kuat dalam permasalahan yang dihadapi seseorang, setiap orang pasti membutuhkan bantuan afeksi dari orang lain, dukungan berupa empati, simpati, kepedulian, perhatian, cinta, kepercayaan dan penghargaan.

Peran keluarga sangat mempengaruhi keadaan pasien, terutama dalam membantu pasien melakukan apa yang seharusnya dilakukan dalam proses penyembuhan, hal ini sesuai dengan pendapat Anderson (2014), bahwa interaksi pasien dengan keluarga sangat mempengaruhi penyakit yang diderita. Keluarga sebagai penyedia asuhan, ada upaya dan perhatian sosial untuk merawat keluarganya yang sakit.

Peran anggota keluarga dalam memberikan motivasi kepada pasien sakit dibantu oleh anggota keluarga pasien yang dilakukan oleh keluarga baik secara fisik maupun psikis. Bantuan keluarga secara fisik terhadap pasien yaitu memberikan obat dan memasukkan pasien kerumah 
sakit atau secara medis. Sedangkan secara phisikis memberikan kasih sayang, motivasi dan kunjungan rutin terhadap pasien yang berada di Rumah Sakit.

Peran keluarga sebagai motivator dalam penelitian ini menunjukkan sebagian besar baik. Peran keluarga sebagai motivator dapat dilihat dari seberapa sering keluarga mengingatkan hal-hal yang tidak boleh dilakukan karena akan berakibat buruk pada kondisi penyakit.

Peran keluarga sebagai edukator menunjukkan bahwa sebagian besar cukup. Keluarga berperan sebagai pendidik bagi anggota keluarganya yang dapat berfungsi sebagai upaya promotif dari keluarga. Keluarga berkewajiban memberikan pengetahuan kepada seluruh anggota keluarganya, termasuk salah satunya pengetahuan tentang kesehatan. Pendidikan yang rendah dapat berpengaruh terhadap pola pikir dan tindakan keluarga dalam mengatasi masalah dalam keluarga. Sebaliknya dengan tingkat pendidikan tinggi keluarga akan mampu mengenal masalah dan mampu mengambil keputusan untuk menyelesaikan masalah (Effendy \& Makhfudli, 2009).

Untuk langkah pencegahan ini ada beberapa tindakan yang termasuk kriteria eksklusi diantaranya: anjurkan pasien memakai alas kaki anti slip, sediakan kursi roda yang terkunci di samping tempat tidur pasien, tempatkan alat bantu seperti wolkers/ tongkat dalam jangkauan pasien, optimalisasi penggunaan kacamata dan alat bantu dengar, alas kaki anti licin, nilai kebutuhan akan fisioterapi dan terapi okupasi. Untuk pencegahan resiko jatuh dapat dilakukan dengan memosisikan tempat tidur dengan rendah, memastikan nurse call dalam jangkauan, memastikan lingkungan aman seperti lantai yang tidak boleh licin dan pencahayaan yang cukup.

Peran keluarga sebagai fasilitiator menunjukkan bahwa sebagian besar baik. Sebagai fasilitator, keluarga berkewajiban memfasilitasi segala keperluan anggota keluarganya dalam semua aspek baik fisik, mental dan spiritual. Peran keluarga sebagai fasilitator dapat dilihat dari ketersediaan keluarga mengantar penderita berobat ke puskesmas atau pelayanan kesehatan, bersedia mengurus dan membiayai biaya perawatan dan pengobatan. Keluarga juga harus berperan aktif dalam meningkatkan kesehatan anggota keluarganya. Lantai yang licin dapat menjadi risiko terjadinya jatuh. Kurangnya kerjasama antara perawat dan orang tua dalam menjaga lingkungan yang aman dan kondusif membuat lingkungan berisiko untuk pasien jatuh. Hal ini dikarenakan pasien yang muntah atau air yang tumpah. Orang tua biasanya 
akan melapor ke perawat dan perawat akan meminta petugas kebersihan untuk membersihkan karena petugas kebersihan tidak selalu ada di ruangan.

Peran keluarga sebagai inisiator menunjukkan bahwa sebagian besar kurang. Sebagai inisoator, keluarga harus dapat mengemukakan dan menciptakan ide-ide baru yang bertujuan untuk mengatasi masalah kesehatan bagi anggota keluarganya. Selain itu kemampuan keluarga dalam mengambil keputusan juga terbatas karena keluarga tidak mengetahui secara luas tentang masalah penyakit.

Peran keluarga sebagai pemberi perawatan menunjukkan bahwa sebagian besar baik. Sebagai care giver keluarga dapat merawat anggota keluarga yang sakit dengan sungguhsungguh dan memberikan perawatan ketika anggota keluarganya mengeluh sakit.

Peran keluarga sebagai koordinator dan mediator menunjukkan bahwa sebagian besar baik. Keluarga merencanakan dan memutuskan secara musyawarah terkait dengan perawatan anggota keluarganya yang menderita penyakit. Dalam hal ini keluarga sudah dapat berkoordinasi dengan tenaga kesehatan untuk memberikan pengobatan bagi anggota keluarga yang sakit selain itu keluarga juga sudah menggunakan fasilitas kesehatan yang tersedia.

\section{Penutup}

Keselamatan Pasien (Patient Safety) merupakan sesuatu yang jauh lebih penting dari pada sekedar efisiensi pelayanan. Keluarga sebagai lingkungan terdekat pasien merupakan sumber pengetahuan dan persepsi individu terhadap kesehatan. Partisipasi keluarga dan agama menjadi kunci pengelolaan kualitas hidup pada pasien. Peran keluarga sangat mempengaruhi keadaan pasien, terutama dalam membantu pasien melakukan apa yang seharusnya dilakukan dalam proses penyembuhan, hal ini sesuai dengan pendapat Anderson (2014), bahwa interaksi pasien dengan keluarga sangat mempengaruhi penyakit yang diderita. Keluarga sebagai penyedia asuhan, ada upaya dan perhatian sosial untuk merawat keluarganya yang sakit.

\section{Daftar Pustaka}

Tutiany, Lindawati, Krisanti, P. 2017. Bahan Ajar Keperawatan : Manajemen Keselamatan Pasien. Jakarta : Pusdik SDM Kesehatan

Lombogia, A., Rottie, J., Karundeng, M. 2016. Hubungan Perilaku Dengan Kemampuan Perawat Dalam Melaksanakan Keselamatan Pasien (Patient Safety) Di Ruang Akut Instalasi Gawat Darurat RSUP Prof. Dr. R. D. Kandou Manado. e-journal Keperawatan, 4(2), 1-8 
Werdhani, R. A., Setiawati, E. P., Rinawan, F. R. 2017. Peran Keluarga dalam Pengelolaan Kasus di Layanan Primer Melalui Five Family Oriented Questions. eJKI, 5 (1), 18-26

Nurhasanah, A., Nurdahlia. 2020. Edukasi Kesehatan Meningkatkan Pengetahuan Dan Keterampilan Keluarga Dalam Pencegahan Jatuh Pada Lansia. JKEP, 5 (1), 82-100

Dewi, T., Noprianty, R. 2018. Phenomenologi Study: Risk Factors Related To Faal Incidence In Hospitaliced Pediatric Patient With Theory Faye G. Abdellah. NurseLine Journal, 3 (2), 8188

Ayuningtiyas, P. Y. 2019. Gambaran Peran Keluarga Dalam Merawat Anggota Keluarga Yang Mengalami Osteoartritis Di Desa Jetis. Skripsi pada Fakultas Ilmu Kesehatan, Universitas Muhammadiyah Surakarta

Ningsih, S. S. 2017. Pengalaman Keluarga Menghadapi Hospitalisasi Pasien Kritis Di Ruang ICU RSUP Dr. Kariadi Semarang. Skripsi pada Fakultas Kedokteran, Universitas Diponegoro Putri, J., Marni, E., Adila, D. R. 2019. Hubungan Kunjungan Keluarga Terhadap Kesembuhan Pasien Risiko Perilaku Kekerasan Di Rumah Sakit Jiwa Tampan Pekanbaru. Jurnal Ners Indonesia, 9 (2), 163-170

Melia, Y. 2016. Upaya Keluarga Dalam Penyembuhan Pasien Penyakit Jiwa; Studi Pada Pasien Penyakit Jiwa di RSJ HB. Sa'anin Padang. Jurnal Ilmu Sosial Mamangan, 5 (2), 102-112

Ruwayda. 2015. Hubungan Nyeri, Peran Keluarga, Dan Peran Petugas Kesehatan Dengan Pelaksanaan Mobilisasi Dini Pada Pasien Pasca Operasi Sectio Caesaria Di Ruang Kebidanan RSUD Raden Mattaher Jambi Tahun 2015. Jurnal Poltekkes Jambi, 12 (3), 141-149

Widiati, A., Ernawati, P. 2017. Hubungan Dukungan Perawat Dan Dukungan Keluarga Dengan Tingkat Kecemasan Pasangan Hidup Pasien Yang Dirawat Di Ruang ICU Rumah Sakit Wilayah Kabupaten Blora. Jurnal SMART Keperawatan Sekolah Tinggi Ilmu Kesehatan (STIKes) Karya Husada Semarang, 4 (1), 72-84

Simamora, R. H. (2019). Buku ajar pelaksanaan identifikasi pasien. Uwais Inspirasi Indonesia. 